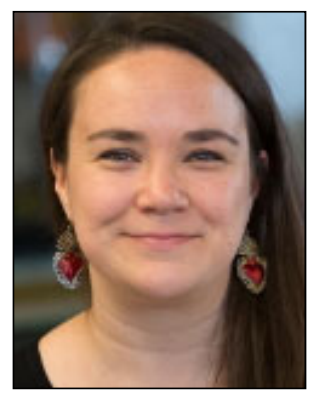

\author{
Cultivating Comida: \\ Pushing the Borders of Food, Culture, ANd Politics \\ Teresa M. MARes
}

\title{
Farmworker gardens and food sovereignty in the northern borderlands
}

Citation: Mares, T. M. (2017). Farmworker gardens and food sovereignty in the northern borderlands. Journal of Agriculture, Food Systems, and Community Development, 8(1), 5-8. http://dx.doi.org/10.5304/jafscd.2018.081.007

Copyright (C) 2018 by the Author. Published by the Lyson Center for Civic Agriculture and Food Systems. Open access under CC BY license.

$\mathrm{F}_{\mathrm{t} \text { en }}$ or Maria, the small kitchen garden that she tends behind her house brings a sense of balance to her family and a sense of agency over the food that sustains them. As she explained to me, "The garden balances us. What we harvest from the garden is healthier for me and my kids and my family because it is fresher. My kids also help in the garden with preparing the soil, learning

Dr. Teresa Mares is associate professor of anthropology at the University of Vermont. Her research focuses on the intersection of food and migration studies, and particularly how diets and foodways of Latino/a immigrants change as a result of migration. She is currently examining border politics and food access issues among Latino/a dairy workers in Vermont and is writing a book on this topic, entitled The Other Border: Sustaining Farmworkers in the Dairy Industry, under contract with University of California Press. Recent publications include "Navigating Gendered Labor and Local Food: A Tale of Working Mothers in Vermont," in Food and Foodways, and a co-authored chapter, "Eating Far from Home: Latino/a Workers and Food Sovereignty in Rural how to plant. And maybe in the future, they will continue doing it." A mother of five from the southern Mexican state of Guerrero, Maria has lived in the United States for the past 13 years, supporting her husband who has worked on industrial dairy farms, first in New York and now in Vermont. While she raises her children and tends to her garden and free-range chickens, she acts as the primary caretaker and cook for their

Vermont," in Food Across Borders: Production, Consumption, and Boundary Crossing in North America.

Outside the classroom, Dr. Mares has led a number of community food projects. She is co-director of Huertas, a food security project for Latino/a dairy farmworkers connected to UVM Extension's Bridges to Health Program, and was previously co-director of the Food Justice Project for the Community Alliance for Global Justice in Seattle. She is devoted to experiential, transformative modes of teaching and has advised dozens of students who seek to make a difference in the contemporary food system. She can be reached at Teresa.Mares@uvm.edu. 
household during the long hours that her husband spends in the milking barn. Maria has some serious skills in the kitchen, and she loves to share dishes that remind her of Mexico with her children, whose only memories are of rural Vermont. And yet, despite having a relatively stable household income, Maria's family still struggles with severe food insecurity. The vegetables and eggs that Maria harvests from her garden and chicken coop, along with support in the form of WIC benefits and free school meals, have been essential in keeping her children fed.

Maria's husband is one of the estimated 1,000 to 1,200 farmworkers from Latin America who help to sustain Vermont's dairy economy. Over the past six years, I have studied issues of food insecurity within the state's farmworker community and the strategies they engage to access food for their households. As I described in my previous Cultivating Comida column (Mares, 2017), farmworkers' access to food and other basic needs is compromised by border proximity and the fears that many farmworkers experience because of regular surveillance from Border Patrol and Immigration and Customs Enforcement (ICE) personnel. However, despite some of the particularities of the Vermont context, food insecurity is not unique to farmworkers in the state. Researchers before me have documented the severity of food insecurity and other inequalities in food access among farmworkers across the country (Borre, Ertle, \& Graff, 2010; Brown \& Getz, 2011; Cason, Nieto-Montenegro, \& Chavez-Martinez, 2006; Essa, 2001; Harrison, Stormer, Herman, \& Winham, 2003; Kilanowski \& Moore, 2010; Kresge \& Eastman, 2010; Minkoff-Zern, 2014; Moos, 2008; Quandt, Arcury, Early, Tapia, \& Davis, 2004; Sano, Garasky, Greder, Cook, \& Browder, 2011; Villarejo et al., 2000; Weigel, Armijos, Hall, Ramirez, \& Orozco, 2007; Wirth, Strochlic, \& Getz, 2007). Collectively, these studies reveal that the incidence of food insecurity among farmworkers is as high as 3 to 4 times the national average, with a disproportionate number of households experiencing what the USDA terms "very low food security with hunger." Based on the food security survey I conducted with Maria, I know that her family is grappling with this most severe form of food insecurity. This food injustice represents a glaring contradiction of our food system: those who put food on our tables are disproportionately experiencing food insecurity in their own homes.

In my previous writing, I have examined how gardens serve as a significant source of sustenance and the maintenance of cultural identities, especially in the midst of migration and settlement

(Mares \& Peña, 2011; Mares, Wolcott-MacCausland, \& Mazar, 2017). It is also the case that immigrant gardens are an important site to cultivate food sovereignty, particularly in the face of assimilatory forces and xenophobia. In her book The Earth Knows My Name, Patricia Klindienst (2006) observes that garden metaphors have long been used to describe the migration experience, particularly in metaphors of being uprooted or transplanted. She proposes to reverse the metaphor, to focus on the immigrant as a gardener rather than an uprooted plant: "a person who shapes the world rather than simply being shaped by it" (Klindienst, 2006, p. xxi). Through presenting beautifully descriptive case studies of U.S. ethnic and immigrant gardeners, Klindienst argues that "to garden is to claim a portion of American soil as their symbolic home, even when they can never hope to own any land" (Klindienst, 2006 , pp. xxii-xxiii). For Maria's family, the connection they have with the land they cultivate is indeed tenuous, yet it still fosters a sense of food sovereignty and belonging.

While food sovereignty is at the heart of largescale social movements, it is also crucial to recognize the smaller, more immediate instances of food sovereignty that marginalized communities practice on a daily basis. In her 2017 book We W ant Land To Live, Amy Trauger connects the larger vision of 
food sovereignty to this more intimate scale, arguing that,

"the material struggle for land, food, and seed advances on multiple fronts, mostly on small farms and in local communities, and through small, but significant acts of defiance, as well as through acts of kindness and lovethe "practice of freedom" (hooks, 2006), made in everyday ways by ordinary people." (Trauger, 2017, p. 2)

Through her garden, Maria practices acts of defiance and of love as she fosters a deeper connection between her family and their food, even amidst the serious food insecurities they encounter. And yet the freedom and agency that she cultivates are perhaps even more important than the food she grows, and she hopes that this agency is passed down to her children as they develop their own relationships to food.

As the Huertas project (see sidebar) works to enhance the sovereignty that farmworker families like Maria's have over the food that sustains them, we are well aware that our efforts represent just one small, and seasonally dependent, dimension of household food access. For many families like Maria's, government support in the form of WIC and free lunch programs supplement the wages earned from the dairy industry and are essential in maintaining even the precarious household food security they experience. Seen another way, this reliance on governmental support represents another hidden cost of industrial food production
Since 2011, as I have studied these food security issues, I have served as Huertas began as an informal project in $\mathbf{2 0 1 0}$ when my colleague, Naomi plants would help to improve access to more localized and culturally encounter, so that I could guide my research in an applied and communitybased manner. Since then, my faculty position at a land-grant institution has also allowed me to leverage university resources to strengthen our rk and create opportunities for student volunteers and interns to we now conduct early-season surveys with all participating households to develop an inventory of requested seeds and starts that we use to solicit donations from local growers and seed suppliers, rather than distributing extra plants that may or may not address farmworkers' needs or priorities. We have done so with the goal of increasing the choice and agency that growers have over the gardens they cultivate, transforming the guiding principles underlying our work from those informed by a discourse of food security to one of food sovereignty.

\section{References}

Borre, K., Ertle, L., \& Graff, M. (2010). Working to eat: Vulnerability, food insecurity, and obesity among migrant and seasonal farmworker families. American Journal of Industrial Medicine, 53(4), 443-462. https://doi.org/10.1002/ajim.20836

that is not accounted for in the price we pay for milk. However, this contradiction is not unique to the dairy industry; across the food system, povertylevel wages keep food and farmworkers in vulnerable economic positions. National organizations like the Food Chain Workers Alliance and local organizations like Vermont-based Migrant Justice are tackling these issues head-on as they demand justice and sustainable livelihoods for the workers who bring food from farms, factories, and restaurants to our tables. In my next column, I will delve further into these worker-led efforts to transform our food system and how they bring greater dignity to families like Maria's. 
Brown, S., \& Getz, C. (2011). Farmworker food insecurity and the production of hunger in California. In A. H. Alkon \& J. Agyeman (Eds.), Cultivating food justice: Race, class, and sustainability (pp. 121-146). Cambridge, Massachusetts: MIT Press.

Cason, K., Nieto-Montenegro, S., \& Chavez-Martinez, A. (2006). Food choices, food sufficiency practices, and nutrition education needs of Hispanic migrant workers in Pennsylvania. Topics in Clinical Nutrition, 21(2), 145-158. https://doi.org/10.1097/00008486-200604000-00010

Essa, J. S. (2001). Nutrition, bealth, and food security practices, concerns, and perceived barriers of Latino farm/industry workers in Virginia (Master's thesis). Virginia Tech, Blacksburg, Virginia. Retrieved from https://vtechworks.lib.vt.edu/handle/10919/34450

Harrison, G. G., Stormer, A., Herman, D. R., \& Winham, D. M. (2003). Development of a Spanish-language version of the U.S. household food security survey module. The Journal of Nutrition, 133(4), 1192-1197. https://doi.org/10.1093/in/133.4.1192

Kilanowski, J. F., \& Moore, L. C. (2010). Food security and dietary intake in Midwest migrant farmworker children. Journal of Pediatric Nursing, 25(5), 360-366. https://doi.org/10.1016/j.pedn.2009.04.008

Klindienst, P. (2006). The earth knows my name: Food, culture, and sustainability in the gardens of ethnic Americans. Boston, Massachusetts: Beacon Press.

Kresge, L., \& Eastman, C. (2010). Increasing food security among agricultural workers in California's Salinas Valley. Davis: California Institute for Rural Studies. Retrieved from http://www.cirsinc.org

Mares, T. M. (2017). Cacao fields and dairy cows: The interdependencies between Mexican workers and the U.S. food system. Journal of Agriculture, Food Systems, and Community Development, 7(4), 9-12. https://doi.org/10.5304/jafscd.2017.074.010

Mares, T. M., \& Peña, D. G. (2011). Environmental and food justice: Toward local, slow, and deep food systems. In A. H. Alkon \& J. Agyeman (Eds.), Cultivating Food Justice: Race, Class, and Sustainability (pp. 197-220). Cambridge, Massachusetts: MIT Press.

Mares, T. M., Wolcott-MacCausland, N., \& Mazar, J. (2017). Eating far from home: Latino/a workers and food sovereignty in rural Vermont. In M. Garcia, E. M. DuPuis, \& D. Mitchell (Eds.), Food Across Borders: Production, Consumption, and Boundary Crossing in North America (pp. 181-200). New Brunswick: Rutgers University Press. https://doi.org/10.2307/j.ctt1trkkjk.13

Minkoff-Zern, L.-A. (2014). Knowing "good food": Immigrant knowledge and the racial politics of farmworker food insecurity. Antipode, 46(5), 1190-1204. https://doi.org/10.1111/j.1467-8330.2012.01016.x

Moos, K. (2008). Documenting vulnerability: Food insecurity among indigenous Mexican migrants in California's Central $V$ alley. Washington, D.C.: Congressional Hunger Center. Retrieved from https://www.hungercenter.org/publications/ documenting-vulnerability-food-insecurity-among-indigenous-mexican-migrants-in-californias-central-valley/

Quandt, S. A., Arcury, T. A., Early, J., Tapia, J., \& Davis, J. D. (2004). Household food security among migrant and seasonal Latino farmworkers in North Carolina. Public Health Reports, 119(6), 568-576. https://doi.org/10.1016/j.phr.2004.09.006

Sano, Y., Garasky, S., Greder, K. A., Cook, C. C., \& Browder, D. E. (2011). Understanding food insecurity among Latino immigrant families in rural America. Journal of Family and Economic Issues, 32(1), 111-123. https://doi.org/10.1007/s10834-010-9219-y

Trauger, A. (2017). We want land to live: Making political space for food sovereignty. Athens: University of Georgia Press.

Villarejo, D., Lighthall, D., Williams III, D., Souter, A., Mines, R., Bade, B., .. McCurdy, S. A. (2000). Suffering in silence: A report on the health of California's agricultural workers. Davis: California Institute for Rural Studies.

Weigel, M. M., Armijos, R. X., Hall, Y. P., Ramirez, Y., \& Orozco, R. (2007). The household food insecurity and health outcomes of U.S.-Mexico border migrant and seasonal farmworkers. Journal of Immigrant and Minority Health, 9(3), 157-169. https://doi.org/10.1007/s10903-006-9026-6

Wirth, C., Strochlic, R., \& Getz, C. (2007). Hunger in the fields: Food insecurity among farmworkers in Fresno County. Davis: California Institute for Rural Studies. Retrieved from http://www.cirsinc.org/publications/category/8-ruralhealth\# 